\title{
Stranded humpback whale (Megaptera novaeangliae) (Cetacea: Balaenopteridae) in Paraná River Delta, Buenos Aires Province, Argentina. Comments on the occurrence of marine mammals in the La Plata River Basin
}

\author{
Sergio 0. Lucero ${ }^{1,5}$; María Constanza Gariboldi²; Valeria Bauni ${ }^{3,6}$; Juan Manuel Meluso ${ }^{3,7}$; \\ Daniela del Castillo ${ }^{1,8}$; Federico L. Agnolin ${ }^{3,4,9}$ \& Sergio Bogan ${ }^{3,10}$
}

\footnotetext{
1 Museo Argentino de Ciencias Naturales “Bernardino Rivadavia” (MACN), División Mastozoología, Laboratorio de Ecología, Comportamiento y Mamíferos Marinos. Buenos Aires, Buenos Aires, Argentina.

${ }^{2}$ Universidad Maimónides, Centro de Estudios Biomédicos, Biotecnológicos, Ambientales y Diagnóstico (CEBBAD). Buenos Aires, Buenos Aires, Argentina. E-mail: cotigariboldi@gmail.com

3 Universidad Maimónides, Departamento de Ciencias Naturales y Antropológicas, Fundación de Historia Natural Félix de Azara. Buenos Aires, Buenos Aires, Argentina.

${ }^{4}$ Museo Argentino de Ciencias Naturales "Bernardino Rivadavia” (MACN), División Paleovertebrados, Laboratorio de Anatomía Comparada y Evolución de los Vertebrados. Buenos Aires, Buenos Aires, Argentina.

${ }^{5}$ E-mail: serglucero@yahoo.com.ar

${ }^{6}$ ORCID: 0000-0002-3076-8905. E-mail: valeria.bauni@fundacionazara.org.ar

7 E-mail: juan.meluso@fundacionazara.org.ar

${ }^{8}$ E-mail: dld.castillo@gmail.com

${ }^{9}$ ORCID: 0000-0001-5073-561X. E-mail: fedeagnolin@yahoo.com.ar

${ }^{10}$ E-mail: sergio.bogan@fundacionazara.org.ar
}

\begin{abstract}
The humpback whale (Megaptera novaeangliae) is distributed among most oceans and seas of the globe (except Mediterranean Sea). These whales migrate from feeding regions in the Antarctic waters to breeding areas in tropical and subtropical seas. Here we report the stranding of a female young humpback whale, which was founded dead in the vicinity of the Talavera Island, in the Paraná River Delta, Buenos Aires Province, Argentina. From the analysis of mitochondrial cytochrome c oxidase subunit I gene sequences, two novel haplotypes were found, totalizing four haplotypes described for the species. In the La Plata River Basin this species was found only twice at the end of the XIX century. Thus, the new finding constitutes an important addition to the list of cetaceans that occurs in Uruguay, Paraná and La Plata Rivers.
\end{abstract}

Key-Words. Megaptera novaeangliae; Humpback whale; Delta del Río Paraná; Haplotypes; Argentina.

\section{INTRODUCTION}

The humpback whale (Megaptera novaeangliae) is a misticete cetacean that is distributed among most oceans and seas of the globe, with the exception of the Mediterranean Sea (Clapham \& Mead, 1999; Clapham, 2002). These whales migrate from the feeding regions in the Antarctic Waters to breeding areas in tropical and subtropical seas (e.g., Mackintosh, 1942; Dawbin, 1966; Clapham \& Mead, 1999; Clapham, 2002). In the Southern Hemisphere humpback whales have seven feedings areas (Dawbin, 1966; Clapham \& Mead, 1999; Clapham, 2002; IWC, 2005). One of them, The Breeding Stock A, is distributed along the Southwestern Atlantic Ocean and constitutes one of the least known breeding groups (Andriolo et al., 2010). This stock breeds at the Brazilian coasts, at the Abrolhos Bank, where approximately 3,500 individuals were censed (Engel, 1996; Martins et al., 2001; Zerbini et al., 2006, 2011; Andriolo et al., 2010). Genetic studies have the potential to provide data allowing to descipher long-term patterns of affiliation, breeding, and dispersal, as well as to understand important topicas on social and geographical structures of populations. In spite to that, detailed genetic studies of Humpback whales in the Southwestern 
Atlantic are still wanting, and the report of any evidence is urgently needed.

In the Argentine Sea the records are scarce, and this is probably because humpback whales migrate across very deep seas and avoid the large continental platform of Argentina. In this way, the strandings of the species are scarce and mostly correspond to isolated individuals (see Angeletti et al., 2014). Strandings are reported from Buenos Aires Province, Chubut Province, Tierra del Fuego Province and Islas Malvinas (e.g., Lichter \& Hooper, 1984; Bastida \& Rodríguez, 2009; Angeletti et al., 2014).

The aim of the present paper is to report the stranding of a female young humpback whale, which was found dead in vicinity of the Talavera Island, in the Paraná River Delta, Buenos Aires Province, Argentina. Further, we explore the genetic identification of the species and the historical revision of the occurrence of marine mammals in the La Plata River basin.

\section{MATERIALS AND METHODS}

\section{Stranding}

The 21 of July of 2012 a large cetacean swimming at the Paraná River was reported by local people of Zárate town. Some days later, presumably the same individual was observed in San Pedro locality, and on July $25^{\text {th }}$, the cetacean was found dead at the proximities of Talavera Island $\left(33^{\circ} 56^{\prime} 00,75^{\prime \prime} \mathrm{S} ; 58^{\circ} 58^{\prime} 02,82^{\prime \prime} \mathrm{W}\right)$. The Talavera Island is located at the $4^{\text {th }}$ section of the Delta del Paraná, at Zárate Township, emplaced at northeastern Buenos Aires Province (Fig. 1). This area is lined by a large number of watercourses, the most important being the Paraná River, that ends in the La Plata River and conforms a wide delta.

\section{Genetic analyses}

Tissue samples from the individual found in Talavera Island were collected (FHNA, hereafter). Additionally, we analyzed a sample from another individual found in Punta Alta, southern Buenos Aires province, Argentina (FHNB, hereafter). This specimen consist on skin samples and epizooic barnacles of a male specimen collected at $18 / 11 / 2011$ and housed under the collection number CFA-MA-13095. This specimen was reported and its finding published in detail by Angeletti et al. (2014). Total DNA was extracted using a proteinase $\mathrm{K}$ digestion, extraction of proteins with phenol-chloroform method and alcohol precipitation of DNA (Sambrook et al., 1989). A fragment of $711 \mathrm{bp}$ from the mitochondrial cytochrome c oxidase subunit I gene (COI) was amplified by polymerase chain reaction (PCR) using primers FHNF 5' ATT CTC AAC CAA CCA CAA AG y FHNR 5' GTG AAA TTA TTC CGA AGC CA, specially designed for this study. Final concentrations used in PCR reaction volumes of $50 \mathrm{ul}$ were: $5 \mu \mathrm{g} / \mathrm{ml}$ template DNA, Buffer 1X (Promega), $0.2 \mathrm{mM}$ dNTPs, $0.2 \mu \mathrm{M}$ each primer, $1.5 \mathrm{mM}$ de $\mathrm{MgCl}_{2}$ y 1.25 units of GoTaq polymerase (Promega). PCR cycling profile consisted
Table 1. Cytochrome c oxidase subunit I gene sequences analyzed and its geographic location.

\begin{tabular}{cc}
\hline GenBank Accession number & Geographic Location \\
\hline AP006470 & Antartic \\
EU139285 & Northwestern USA \\
EU139286 & Northwestern USA \\
EU496287 & Northwestern USA \\
FJ590425 & Unknown \\
GQ353284 & USA \\
GQ353285 & USA \\
GQ353286 & USA \\
KY001615 (FHNB) & This study/Argentina \\
KY001616 (FHNA) & This study/Argentina \\
NC006927 & Antarctic \\
\hline
\end{tabular}

of an initial denaturation at $94^{\circ} \mathrm{C}$ for $2 \mathrm{~min}$, followed by thirty-five cycles of denaturation at $94^{\circ} \mathrm{C}$ for $1 \mathrm{~min}$, anneling at $50^{\circ} \mathrm{C}$ for $1 \mathrm{~min}$, and extension at $72^{\circ} \mathrm{C}$ for $1 \mathrm{~min}$, and a final extension at $72^{\circ} \mathrm{C}$ for $5 \mathrm{~min}$. PCR products were purified using a commercial kit (AccuPrep PCR Purification Kit, Bioneer) and sequenced in both direction using an $\mathrm{ABI} 337$ Automated DNA Prism Sequencer (Applied Biosystems, Inc.). Sequences were aligned using CLUSTALX 2.0.11 (Larkin et al., 2007) and compared with those previously published for the species (Genbank: NC006927, GQ353284, GQ353285, GQ353286, FJ590425, EU139285, EU139286, EU496287) (Table 1). From the 711 bp amplified, a 593 bp consensus region containing most variation was examined. Haplotypes were verified using DnaSP v5.10.01 (Librado \& Rozas, 2009). To study patterns of geographical distribution and relationships among haplotypes, we implemented a Median-Joining

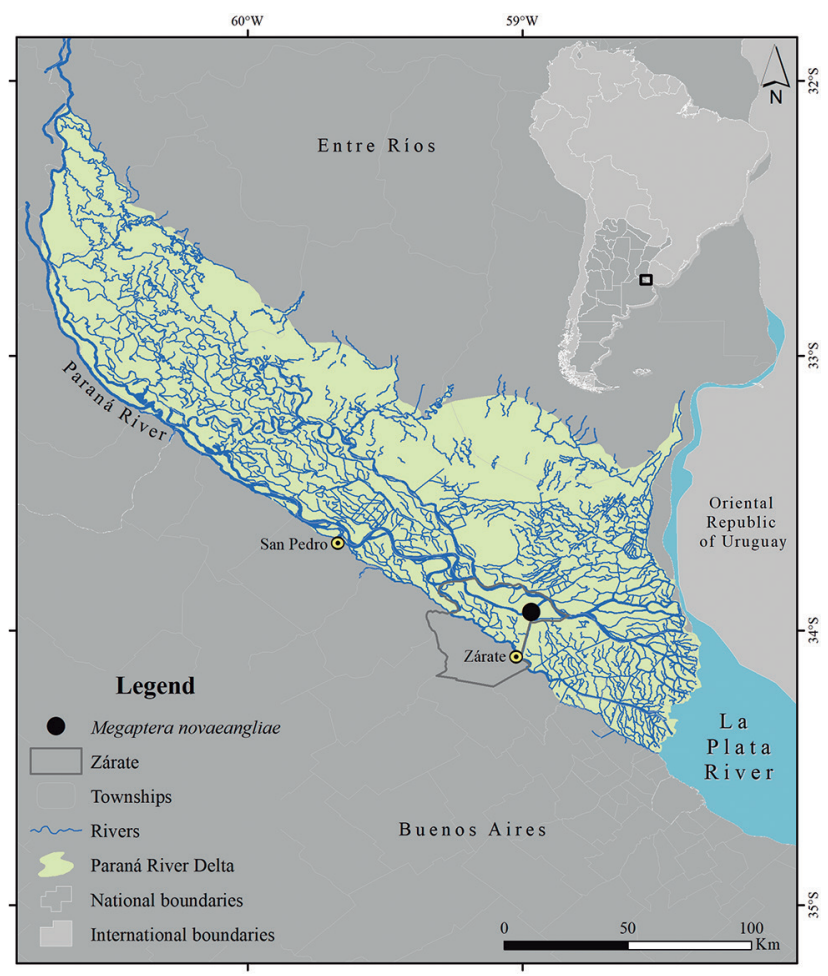

Figure 1. Paraná River delta map were Megaptera novaeangliae (CFA-MA-13084) was found dead (exact location is indicated with a black dot). 
network (Bandelt et al., 1999) in PopART 1.7 (Leigh \& Bryant, 2015).

\section{RESULTS}

The stranded specimen was found floating in the watercourse and resting on its right side. With the help of a backhoe and a crawler the individual was aground in the island coast to proceed with its preparation. Although its body surface was in a good state of preservation, the inner organs and its musculature were badly decomposed and its thumb was inflated by organic gas. Therefore, details of inner anatomy were not available for study (Fig. 2).

The stranded individual showed a combination of characters that unambiguously identify it as belonging to Megaptera novaeangliae: pectoral fins notably enlarged, representing $1 / 3$ of total body length, festooned margins of pectoral fins, entirely black dorsal coloration, and head and body with a midline row of bumps, among other features (Lichter \& Hooper, 1984; Bastida \& Rodríguez, 2009).

The skeleton, one eye and samples of fat, skin, and muscles were housed at the Mastozoology Collection of the Fundación de Historia Natural "Félix de Azara", Buenos Aires, Argentina (CFA-MA-13084) (Fig. 3).

The individual was 10.09 meters long and was classified as a juvenile, since the length of adult specimens range from 14 to 16 meters (Clapham \& Mead, 1999). Furthermore, analysis of genitalia identified it as a female (Table 1).

Five deep transverse cuts (being approximately $5 \mathrm{~cm}$ wide and more than $30 \mathrm{~cm}$ depth) were found on the left lateral side of the head of the individual, which would correspond to the impact of the propeller of a large boat on the cetacean. This certainly constitutes the cause of death of the specimen.

As other individuals of this species, its body was covered by a large number of cirripedes, specially the protuberances of the head and the anterior margin of the pectoral fins. Cirripedes were determined as Conchoderma auritum (Cirripedia, Lepadidae), an epibionthic crusta-
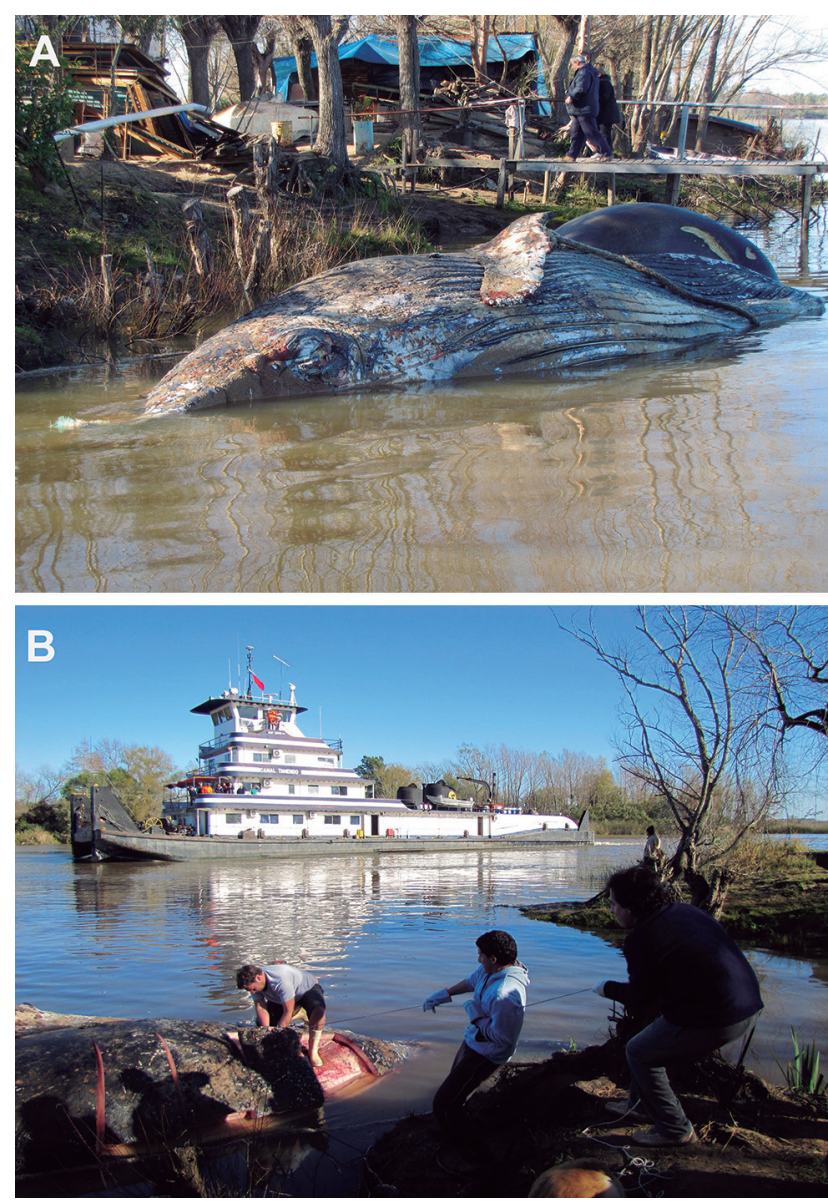

Figure 2. (A) CFA-MA-13084 specimen before start preparation. (B) Sampling extraction work.

cean frequently found in Megaptera novaeangliae (Clarke, 1966; Zullo, 1979; Félix et al., 2006; Angeletti et al., 2014).

\section{Geographical distribution and relationships among haplotypes}

From the analysis of the samples FHNA and FHNB, two novel haplotypes were found (GenBank accession numbers: KY001616 and KY001615, respectively) (Table 1).

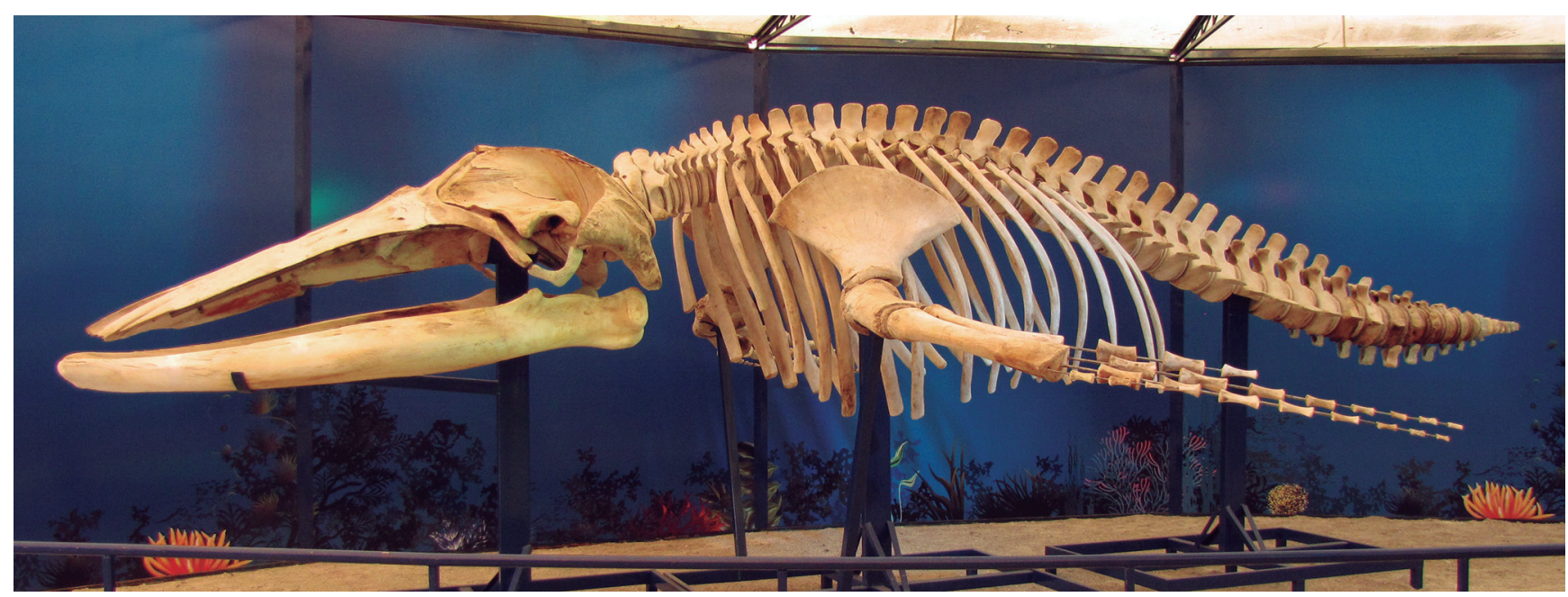

Figure 3. Megaptera novaeangliae (CFA-MA-13084) mounted skeleton. 
Table 2. Polymorphic sites within 11 cytochrome c oxidase subunit I gene sequences from Megaptera novaeangliae.

\begin{tabular}{cc}
\hline GenBank Accession number & Geographic Location \\
\hline AP006467 & Antartic \\
EU139285 & Northwestern USA \\
EU139286 & Northwestern USA \\
EU496287 & Northwestern USA \\
FJ590425 & Unknown \\
GQ353284 & USA \\
GQ353285 & USA \\
GQ353286 & USA \\
KY001615 (FHNB) & This study/Argentina \\
KY001616 (FHNA) & This study/Argentina \\
NC006927 & Antarctic \\
\hline
\end{tabular}

Note: For each haplotype, a dot indicates a nucleotide identical to the reference haplotype AP006467 at that given site.

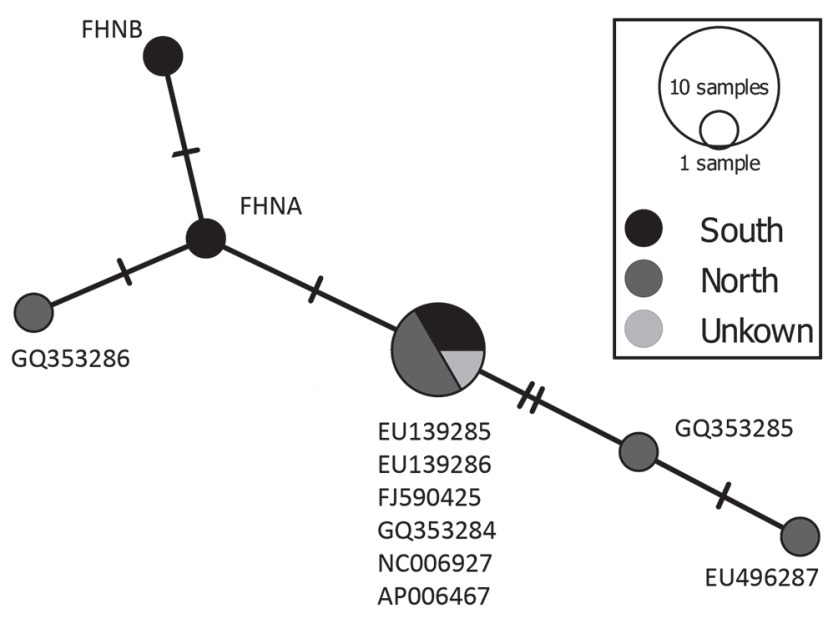

Figure 4. Median-joining network based on the cytochrome c oxidase subunit I mtDNA haplotypes of Megaptera novaeangliae. Haplotypes are represented with discs and colors that indicate geographical locations. Mutational steps are indicated with stripes.

Based on the our analysis, six sequences (EU139285-6, FJ590425, GQ353284, AP006467 and NC006927) conform a common haplotype (see Appendix 1). However, since a consensus region was analyzed, mutations pres- ent beyond the consensus region length were lost and those haplotypes were grouped together (Table 2). Additionally, no phylogeographic pattern was evident based on the network results (Fig. 4).

\section{DISCUSSION}

\section{Occurrence of cetaceans in the La Plata River basin}

Humpback whales migrate notable long distances that may overcome more than $8,000 \mathrm{~km}$, being probably the longest distance achieved by any mammal species (Mackintosh, 1942). Humpback whales feed in summer and spring in cold regions and during winter and autumn migrate towards breeding areas in tropical and subtropical seas (Bastida \& Rodríguez, 2009; Angeletti et al., 2014). This whale is very scarce in Argentina, probably because it avoids the shallow waters of its continental platform. In fact, there has only been approximately 15 sights and strandings from 1866 to the date (see Table 3).

In the La Plata River Basin, the species has been found only twice at the end of the XIX century (Burmeister, 1867; Lahille, 1899a). Thus, this new finding constitutes an important addition to the list of cetaceans that occurs in Uruguay, Paraná and La Plata rivers.

Since the pioneering works of Burmeister at the second half of the XIX century, a large number of cetaceans were found penetrating freshwater courses of the La Plata Basin (Appendix 2). In fact, at least 19 cetacean species, and 4 pinnipeds (Carman, 2009) were found in these watercourses. These include the finding of a blue whale in the intersection between Luján and Paraná rivers by Burmeister (1872). Further, Burmeister (1867) and Lahille $(1899 a, b)$ mentioned fin whales in localities at the La Plata River coast. In addition, the holotype of the Antarctic Minke Whale, Balaenoptera bonaerensis, was found in the La Plata River, at shores of the Buenos Aires city (Burmeister, 1867; Zerbini \& Castello, 2003). Minke whales are fairly common along the La Plata River coast, and the stranding of juveniles is not an uncommon fact (Marelli, 1918; Lichter \& Hooper, 1984).

Table 3. Sights and strandings of Humpback whales from 1866 to the date in Argentina.

\begin{tabular}{|c|c|c|c|c|}
\hline Locality & Sex & Age & Date & Observations \\
\hline Buenos Aires coast & & & & Gray, 1866 \\
\hline Island between Paraná Guazú and Paraná de las Palmas rivers, Buenos Aires province & & & & Burmeister, 1866, 1867 \\
\hline Punta Indio, Buenos Aires province & & & & Lahille, 1899b \\
\hline Punta Indio, Buenos Aires province & & & & Lahille, 1905 \\
\hline Beagle Channel, Tierra del Fuego province & & & & Lahille, 1905 \\
\hline Patagonia and Islas Malvinas & & & & Mörch, 1911 \\
\hline Islas Malvinas & & & & Salvesen, 1914 \\
\hline Islas Malvinas & & & & Carcelles, 1932 \\
\hline Islas Malvinas & & & & Hamilton, 1952 \\
\hline Punta Ushuaia, Tierra del Fuego. & M & Juvenile & & Angeletti et al., 2014 \\
\hline Punta Tejada, Buenos Aires province & M & Juvenile & 22 Julio 2011 & Angeletti et al., 2014 \\
\hline Delta del Paraná, Buenos Aires province & $\mathrm{F}$ & Juvenile & & Present work \\
\hline Ciudad Autónoma de Buenos Aires port & & & 3-4 Agosto 2015 & Present work, specimen observation aground \\
\hline Mar del Tuyú, Buenos Aires province. & & & 19 Julio 2016 & Present work, observation of specimen aground \\
\hline
\end{tabular}


Considerable literature has been devoted to the potential causes of cetacean strandings (see Simmonds, 1997 for a review). Among the most important are the individuals that became lost during migrations, and specimens with some kind of illness, parasites or injuries (Martin et al., 1990). These specimens are in a condition in which they cannot navigate or swim properly and thus accidentally comes ashore. The same may be applied to the occasional or accidental penetration of cetaceans in some freshwater courses (see Smith \& Jefferson, 2002).

However, the record of cetaceans penetrating La Plata Basin watercourses (e.g., Paraná, Uruguay, and La Plata rivers) is notably common (as explained above, at least 19 different species of cetaceans have been reported), and lost individuals are frequently found swimming in their waters. This pattern is not matched by other freshwater courses in the globe. The abnormal frequency of Cetaceans in these waters may have a special explanation. Some authors (Green, 1945 in Dudok van Heel, 1962) defended the idea that some cases of strandings may be due to whales that are attempting to follow ancient migration routes through areas that have been closed by changes in sea level or sediment deposition.

In this regard, the coastal plains and surrounding areas in the south of Entre Ríos Province, together with the Paraná Delta and La Plata River have been affected by the late Pleistocene-Holocene post-glacial marine transgression (Cavallotto et al., 2005). The last evidence of this sea-level rise episode is shown as littoral deposits of mid-Holocene age, which contain concentrations rich in sea shells that are frequent in the La Plata Basin, including the La Plata River coast and southern ends of Paraná and Uruguay rivers (Guida \& González, 1984; Fucks \& De Francesco, 2000; Aguirre \& Fucks, 2004; Martínez \& Del Río, 2005). Thus, the La Plata River and the associated watercourses of southern Mesopotamia were neither an estuary nor a deltaic freshwater environment at that moment. Instead, between $6,000-6,500$ and 3,000 years before present were part of a marine gulf (Cavallotto, 2002; Martínez \& Del Río, 2005). Since around 3,000 years before present, there are no new records of marine influence in the area (Martínez \& Del Río, 2005).

It is possible that such pre-La Plata River was an area that constituted at least a passageway for cetaceans during the Holocene. Thus, it is not improbable that cetaceans penetrating into the La Plata River are attempting to follow ancient marine routes that, since the Late Holocene to the present, are freshwater courses unsuitable for marine mammals. Although we recognize that this proposal rests on weak evidence, the unusually large number and diversity of cetaceans found in La Plata Basin may be indirect evidence sustaining this hypothesis.

\section{Insights into Megaptera novaeangliae COI sequence analysis}

Over more than a decade ago, $\mathrm{COI}$ region have been widely studied with the purpose to develop a "barcode" for species (e.g., Arnason et al., 2004; Amaral et al., 2007).
However, as occurs with any new genetic tool, the barcode method still presents some limitations, such as the low availability of intraspecific variation analyses in some species (e.g., Frézal \& Leblois, 2008; Mitchell, 2008). In this study, we have contributed to the knowledge of the genetic diversity of. M. novaeangliae with two novel $\mathrm{COI}$ sequences, extending the number of described sequences from one to three for the southern distribution range of the species, and from nine to eleven for its entire geographical distribution. The lack of a phylogeographic pattern, suggested by the network results, may be due to the low number of sequences previously described for the species and analyzed in this study. In order to develop a robust genetic tool, more analyses of $\mathrm{COI}$ sequences are urgently needed.

\section{ACKNOWLEDGMENTS}

We thank Departamento de Bromatología y Zoonosis, Prefectura Naval, and Defensa Civil (especially to Mr. Claudio García) of Zárate city for support and help during the extraction of the specimen. We also thank Adrián Giacchino for his help during the fieldwork. Finally, we thank anonymous reviewer and Luis F. Silveira for their enlightening comments on the MS.

\section{REFERENCES}

Aguirre, M. \& Fucks, E. 2004. Moluscos y paleoambientes del Cuaternario marino en el sur de Entre Ríos y litoral bonaerense. Temas de la biodiversidad del litoral fluvial Argentino, 12: 55-70.

Amaral, A.R.; Sequeira, M. \& Coelho, M.M. 2007. A first approach to the usefulness of cytochrome $c$ oxidase I barcodes in the identification of closely related delphinid cetacean species. Marine and Freshwater Research, 58: 505-510.

Andriolo, A.; Kinas P.G.; Engel M.H.; Albuquerque Martins, C.C. \& Rufino, A.M. 2010. Humpback whales within the brazilian breeding ground: distribution and population size estimate. Endangered Species Research, 11:233-243.

Angeletti, S.; Cervellini, P.M. \& Massola, V. 2014. Nuevo registro de ballena jorobada (Megaptera novaeangliae) para el Mar Argentino y notas sobre sus epibiontes. Mastozoología neotropical, 21(2): 319-324.

Arnason, U.; Gullberg, A.\& Janke A. 2004. Mitogenomic analyses provide new insights into cetacean origin and evolution. Gene, 333: 27-34.

Bandelt, H.J.; Forster, P. \& Röhl, A. 1999. Median-joining networks for inferring intraspecific phylogenies. Molecular Biology and Evolution, 16: 37-48.

Bastida, R. \& Rodríguez, D. 2009. Mamíferos marinos de Patagonia y Antártida. Buenos Aires, Vásquez Mazzini Editores. 208p.

Bruch, C. 1916. El macho de Phocaena dioptrica Lah. Physis, 2: 461-462.

Burmeister, H. 1865. Description of a new species of porpoise in the museum of Buenos Ayres. Journal of Zoology, 33(1): 228-231.

Burmeister, H. 1866. On some Cetaceans. Annals and Magazine of Natural History, 18(104): 99-103.

Burmeister, H. 1867. Fauna Argentina. Segunda parte. Mammifera Pinnata Argentina. Anales del Museo Público de Buenos Aires, 1(7): 301-311.

Burmeister, H. 1868. Descripcion de cuatro especies de delfinides de la costa Argentina en el océano atlántico. Anales Museo público Buenos Aires, 1: 367-445. 
Burmeister, H. 1869. Pontoporia blainvillii Gray. Descripción de cuatro especies de delfinides de la costa Argentina en el Océano Atlántico. Anales Museo Público Buenos Aires, 1: 389-445.

Burmeister, H. 1872. On Balaenoptera patachonica and B. intermedia. The Annals and Magazine of Natural History, Serie 4, 10: 413-418.

Carcelles, A. 1932. Tres viajes a los mares antárticos. Physis, 11: 49-81.

Carman, R.L. 2009. Apuntes sobre la fauna argentina. Buenos Aires, Vázquez Mazzini Ed. 139p.

Cavallotto, J.L. 2002. Evolución holocena de la llanura costera del margen sur del Río de la Plata. Revista de la Asociación Geológica Argentina, 57(4): 376-388.

Cavallotto, J.L.; Violante, R.A. \& Colombo, F. 2005. Evolución y cambios ambientales de la llanura costera de la cabecera del río de la Plata. Revista de la Asociación Geológica Argentina, 60(2): 353-367.

Clapham, P.J. \& Mead J.G. 1999. Megaptera novaeangliae. Mammalian Species, 604: 1-9.

Clapham, P.J. 2002. Humpback whale, Megaptera novaeangliae. In: Encyclopedia of marine mammals, San Diego, Academic Press. p. 589-592.

Clarke, R. 1966. The stalked barnacle Conchoderma, ectoparasitic on whales. Norsk Hvalfangst-Tidente, 8: 153-168.

Dawbin, W.H. 1966. The seasonal migratory cycle of humpback whales. In: Norris, K.S. (Ed.). Whales, dolphins and porpoises. Berkley, University of California Press. p. 145-170.

Engel, M. 1996. Comportamento reprodutivo da baleia jubarte (Megaptera novaeangliae) em Abrolhos. In: Encontro Anual de Etologia, 14 . Anais de Etologia. Uberlandia, Sociedade Brasileira de Etologia. p. 275-284.

Félix, F.; Castro, C.; Haase, B.; Forestell, P.; Álava, J.J. \& Scheidat, M. 2006. Estimates of the Southeastern Pacific humpback whale stock with markrecapture models in Ecuador and population trend. Document SC/A06/ HW13 presented in the IWC Workshop on Comprehensive Assessment of Southern Hemisphere Humpback Whales, Hobart, Tasmania: 3-7 April 2006. 7p.

Frézal, L. \& Leblois, R. 2008. Four years of DNA barcoding: current advances and prospects. Infection, Genetics and Evolution, 8: 727-736.

Fucks, E.E. \& De Francesco, F.0. 2000. Rasgos geomorfológicos en el sector inferior del Río Luján, noreste de la Provincia de Buenos Aires, Argentina. In: Congreso Geológico Chileno, 9. Actas. Puerto Varas. v. 1, p. 52-56.

Gray, J.E. 1866. Catalogue of seals and whales in the British Museum. 2.ed. London, British Museum of Natural History. 402p.

Guida, N. \& González, M. 1984. Evidencias paleoestuáricas en el sudeste de Entre Ríos, su evolución con niveles marinos relativamente elevados del Pleistoceno Superior y Holoceno. In: Congreso Geológico Argentino, $9^{\circ}$. Actas. Buenos Aires, Asociacion Geologica Argentina. v. 3, p. 577-594.

Hamilton, J.E. 1952. Cetacea of the Falkland Islands. Comunicaciones Zoologicas Del Museo de Historia Natural de Montevideo, 66, 1-6.

IWC - International Whaling Commission. 2005. Scientific Committee, Anchorage, Alaska. SC/59/SH18 (available from the IWC office).

Lahille, F. 1899a. Ensayo sobre la distribución geográfica de los mamíferos de la República Argentina. In: Reunión del Consejo Científico Latino Americano, $1^{0}$. Buenos Aires, Compania Sud Americana de Billetes de Banco. v. 3, p. 165-206.

Lahille, F. 1899b. Notes sur l'ostéologie du Baleinoptere de Miramar. Revista del Museo de La Plata, 9: 79-120.

Lahille, F. 1905. Las ballenas de nuestros mares, sus costumbres y aprovechamiento. Revista del Jardín Zoológico de Buenos Aires, 1905: 68.

Lahille, F. 1908. Notas sobre un ballenato de 2,10 m de largo (Balaenoptera acutorostrata Lac.). Anales del Museo Nacional, Buenos Aires, 16:375-401.

Lahille, F. 1912. Nota preliminar sobre una nueva especie de marsopa del Río de la Plata, Phocoena dioptrica. Anales Museo Nacional de Historia Natural de Buenos Aires, 23: 271-285.
Larkin, M.A.; Blackshields, G.; Brown, N.P.; Chenna, R.; McGettigan, P.A.; McWilliam, H.; Valentin, F.; Wallace, I.M.; Wilm, A.; Lopez, R.; Thompson, J.D.; Gibson, T.J.; Higgins, D.G. 2007. Clustal W and Clustal X version 2.0. Bioinformatics, 23(21): 2947-2948. PMID: 17846036.

Leigh, J.W. \& Bryant, D. 2015. PopART: Full-feature software for haplotype network construction. Methods in Ecology and Evolution, 6: 1110-1116.

Librado, P \& Rozas, J. 2009. DnaSP v5: a software for comprehensive analysis of DNA polymorphism data. Bioinformatics, 25: 1451-1452. D0I

Lichter, A. \& Hooper A. 1984. Guía para el reconocimiento de los cetáceos del Mar Argentino. Buenos Aires, Fundación vida Silvestre Argentina. 96p.

Mackintosh, N.A. 1942. The southern stocks of whalebone whales. Discovery Reports, 22: 197-300.

Marelli, C.A. 1918. Un ballenato hallado en la costa del río de la Plata. Physis, 4:326-328.

Marelli, C.A. 1920. Revisión osteológica de Berardius arnouxii. Duv. Anales del Museo Nacional de Historia Natural de Buenos Aires, 30: 411-444.

Martin, A.R. 1990. Whales and Dolphins. London, Salamander Books Ltd. 192p.

Martínez, S. \& Del Río, C. 2005. Las Ingresiones marinas del Neógeno en el sur de Entre Ríos (Argentina) y Litoral Oeste de Uruguay y su contenido malacológico. INSUGEO Miscelánea, 14: 13-26. Available at: http:// insuge o.org.ar/libros/misc 14/01.htm.

Martins, C.C.A.; Morete, M.E.; Coitinho, M.H.E.; Freitas, A.C.; Secchi, E.R. \& Kinas, P.G. 2001. Aspects of habitat use patterns of humpback whales in the Abrolhos Bank, Brazil, breeding ground. Memoirs of the Queensland Museum, 47(2): 563-70.

Mermoz, J.F. 1977. Sobre el varamiento de un delfín nariz de botella, T. truncatus, en la desembocadura del Río de la Plata (Buenos Aires, Argentina). Physis Section C, 37(93): 227-235.

Meyen, F.J.F. 1833. Beitrage zür Zoologie. Nova Acta Academicae Cesareae Natur Curios, 16: 549-610.

Mitchell, A. 2008. DNA barcoding demystified. Australian Journal of Entomology, 47: 169-173.

Mörch, J.A. 1911. On the natural history of whalebone whales. Proceedings of the Zoological Society of London, 47: 661-670.

Praderi, R. 1971. Contribución al conocimiento del género Phocoena (Cetacea, Phocoenidae). Buenos Aires, Museo Argentino de Ciencias Naturales Bernardino Rivadavia e Instituto Nacional de Investigación de las Ciencias Naturales.

Praderi, R. 1980. Adiciones a la lista sistemática de cetáceos de Uruguay. In: Jornadas de Ciencias Naturales, $1^{\circ}$. Resumenesy comunicaciones. Montevideo, v. 1, p. 136-137.

Praderi, R. 1981. Varamientos ocasionales de cetáceos en costas del río de la Plata. Jornadas de Ciencias Naturales, $2^{\circ}$. Resumenes y comunicaciones. Montevideo, v. 1, p. 13-14.

Praderi, R. 1985. Notas sobre un varamiento de Balaenoptera musculus Linnaeus, 1758 (Cetacea, Balaenopteridae) en la costa de Colonia, Uruguay. Boletín de la Sociedad Zoológica del Uruguay, (2)3: 16-21.

Salvesen, T.E. 1914. The whale fisheries of the Falkland Islands and Dependencies. In: Report on the Scientific Results of the National Antartic Expedition. Edinburgh, Scottish Oceanographical Laboratory.

Sambrook, J.; Fritsch, E.F. \& Maniatis, T. 1989. Molecular Cloning: a laboratory manual. New York, Cold Spring Harbor Laboratory Press.

Simmonds, M.P. 1997. The meaning of cetacean strandings. Bulletin Institut Royal de Sciences Naturelles de Belgique Biologie, 67: 29-34.

Smith, B.D. \& Jefferson, T.A. 2002. Status and conservation of facultative freshwater cetaceans in Asia. Raffles Bulletin of Zoology, 50: 173-187.

van Heel, W.D. 1962. Sound and cetacea. Netherlands Journal of Sea Research, 1(4): 407-507.

Vaz Ferreira, R. \& Praderi, R. 1973. Un nuevo ejemplar de Kogia breviceps (Blainville), (Cetacea, Physeteridae) del Atlántico sudoccidental. 
Caracteres y notas. In: Congreso Latinoamericano de Zoologia, $5^{\circ}$. Trabajos. Montevideo, Museo Nacional de Historia Natural. p. 261-277.

Zerbini, A.N. \& Castello, H. 2003. Rediscovery of the type specimen of the Antarctic minke whale (Balaenoptera bonaerensis, Burmeister, 1867). Mammalian Biology,-Zeitschrift für Säugetierkunde, 68(2): 118-121.

Zerbini, A.N.; Andriolo, A.; Heide-Jørgensen, M.A.; Pizzorno, J.L.; Maia Y.G.; VanBlaricom, G.R.; DeMaster, D.P.; Simões-Lopes, P.C.; Moreira, S., Bethlem, C. 2006. Satellite-monitored movements of humpback whales Megaptera novaeangliae in the Southwest Atlantic Ocean. Marine Ecology Progress Series, 313: 295-304.
Zerbini, A.N.; Andriolo, A.; Heide-Jørgensen, M.P.; Moreira, S.C.; Pizzorno, J.L.; Maia, Y.G.; Vanblaricom, G. \& Demaster, D.P. 2011. Migration and summer destinations of humpback whales (Megaptera novaeangliae) in the western South Atlantic Ocean. Journal of Cetacean Research and Management, Special Issue, 3: 113-118.

Zullo, V.A. 1979. Marine flora and fauna of the northeastern United States. Arthropoda: Cirripedia. NOAA NMFS Technical Reports Circular, 425: 1-29.

\section{APPENDIX 1}

\section{Sequences analyzed}

M GQ353285. Jackson, J.A.; Baker, C.S.; Vant, M.; Steel, D.J.; Medrano-Gonzalez, L. \& Palumbi, S.R. USA specimen_ voucher="GOM9049.

M EU496287. Viricel, A. \& Rosel, P.E. Evaluating the utility of cox 1 for cetacean species identification. Marine Mammal Science, 28(1): 37-62 (2012) SEFSC:MMMGL:Mnov005.

NC_006927.1.Sasaki, T.; Nikaido, M.; Hamilton, H.; Goto, M.; Kato, H.; Kanda, N.; Pastene, L.A.; Cao, Y.; Fordyce, R.E.; Hasegawa, M. \& Okada, N. Mitochondrial phylogenetics and evolution of mysticete whales. Systematic Biology, 54(1): 77-90 (2005).

GQ353284.1. Jackson, J.A.; Baker, C.S.;Vant, M.; Steel, D.J.; Medrano-Gonzalez, L. \& Palumbi, S.R. Big and slow: phylogenetic estimates of molecular evolution in baleen whales (suborder mysticeti) Mol. Biol. Evol. 26(11), 2427-2440 (2009) specimen_ voucher="SEA87041 USA.

FJ590425.1. Carraher, C.J.F.; Pichler, F.B.; McLenachan, T.; Vant, M. \& Baker, C.S. Efficient Mitogenomic Sequencing of Cetaceans. Unpublished.

D EU139286.1. Zhang, J.; Boriseuko, A.; Ivanova, N.; Hanner, R. \& Hebert, P. DNA Barcoding Alaskan Marine Mammals specimen_voucher=“UAM:Mamm:30552.

EU139285.1. Zhang, J.; Boriseuko, A.; Ivanova, N.; Hanner, R. \& Hebert, P. DNA Barcoding Alaskan Marine Mammals. specimen_voucher=“UAM:Mamm:30661".

GQ353286.1. Jackson, J.A.; Baker, C.S.; Vant, M.; Steel, D.J.; Medrano-Gonzalez, L. \& Palumbi, S.R. Big and slow: phylogenetic estimates of molecular evolution in baleen whales (suborder Mysticeti). Molecular Biology and Evolution. 26(11): 2427-2440 (2009) specimen_voucher="GOM9084"USA. 


\section{APPENDIX 2}

Cetaceans found penetrating freshwater courses of the La Plata Basin. Abbreviations: MACN-Ma Colección de Mastozoología, Museo Argentino de Ciencias Naturales"Bernardino Rivadavia"

\begin{tabular}{|c|c|c|}
\hline Scientific name & Locality & Source \\
\hline Balaenoptera physalus & San Fernando & Lahille (1899a) \\
\hline Balaenoptera physalus & Quilmes & Burmeister (1867) \\
\hline Balaenoptera physalus & Punta Carreta, Montevideo & Praderi (1980) \\
\hline Balaenoptera musculus & Río Luján mouth & Burmeister (1872) \\
\hline Balaenoptera musculus & Bahía de Samborombón & Burmeister (1866) \\
\hline Balaenoptera musculus & Puerto Platero, Colonia & Praderi (1985) \\
\hline Balaenoptera acutorostrata & La Plata River estuary & Castello en Lichter \& Hooper (1984) \\
\hline Balaenoptera acutorostrata & Uruguay coast & Praderi (1981) \\
\hline Balaenoptera bonaerensis & Arroyo Medrano mouth & Burmeister (1867) \\
\hline Balaenoptera acutorostrata & La Plata River & Marelli (1918) \\
\hline Megaptera novaeangliae & Punta Indio & Lahille (1899a) \\
\hline Megaptera novaeangliae & Isla Talavera & This work \\
\hline Berardius arnuxii & Arroyo Pescado & Marelli (1920) \\
\hline Ziphius cavirostris & La Plata River & Burmeister (1867) \\
\hline Ziphius cavirostris & Uruguay coast & Praderi (1981) \\
\hline Ziphius cavirostris & Arroyo Solís grande, Canelones & Praderi (1971) \\
\hline Pontoporia blainvillei & Coast of Buenos Aires City & Burmeister (1869) \\
\hline Pontoporia blainvillei & Punta Lara & Marelli (1951) \\
\hline Kogia breviceps & Playa Ramírez, Montevideo & Vaz Ferreira \& Praderi (1973) \\
\hline Phocoena spinipinnis & La Plata River & Burmeister (1865) \\
\hline Phocoena dioptrica & Quilmes & Lahille (1912) \\
\hline Phocoena dioptrica & Santiago River & Bruch (1916) \\
\hline Orcinus orca & La Plata River estuary & Castello in Lichter \& Hooper (1984) \\
\hline Orcinus orca & Bahía de Samborombón & Padorno in Lichter \& Hooper (1984) \\
\hline Pseudorca crassidens & Bahía de Samborombón & Burmeister (1868) \\
\hline Pseudorca crassidens & Bahía de Samborombón & MACN-MA 20526 \\
\hline Stenella coeruleoalba & La Plata River estuary & Meyen (1833) \\
\hline Tursiops truncatus & Punta Lara & Lichter\& Hooper (1984) \\
\hline Tursiops truncatus & Uruguay River, Gualeguaychú & Burmeister (1866) \\
\hline Tursiops truncatus & Salto Grande dam & Castello in Lichter \& Hooper (1984) \\
\hline Tursiops truncatus & Punta Indio & Mermoz (1977) \\
\hline Feresa attenuata & Punta Indio & MACN-MA 20472 \\
\hline Cephalorhynchus commersonii & Quilmes & MACN-MA? 4.421 \\
\hline Pontoporia blainvillei & Quilmes & MACN-Ma 49.215 \\
\hline Pontoporia blainvillei & Quilmes & MACN-Ma 49.217 \\
\hline Pontoporia blainvillei & Bahía de Samborombón & MACN-Ma 18109 and 18111 and 18115 \\
\hline Pontoporia blainvillei & Punta Indio & MACN-Ma 20507 and 20508 and 20514 \\
\hline Balaenoptera acutorostrata & Buenos Aires port & Lahille (1908) \\
\hline Balaenoptera acutorostrata & San Isidro & MACN-Ma 25.176 \\
\hline Balaenoptera acutorostrata & San Isidro & MACN-Ma 17823 \\
\hline Balaenoptera borealis & Olivos & MACN-Ma 54.107 \\
\hline Balaenoptera acutorostrata & Olivos & MACN-Ma 20520 \\
\hline Balaenoptera acutorostrata & Buenos Aires port & MACN-Ma 20521 \\
\hline
\end{tabular}

